\title{
Pengaruh Pembangunan Manusia Terhadap Pertumbuhan Ekonomi Kota Jambi
}

Oleh:

*) Irmanelly

**)Dosen Tetap STIE Muhaammadiyah Jambi

\begin{abstract}
Abstrak
Salah satu indikator yang umum digunakan untuk mengukur Pembangunan Manusia di suatu wilayah atau Negara adalah Indeks Pembangunan Manusia (IPM), atau dikenal dengan sebutan Human Development Index (HDI) dari UNDP. Indeks Pembangunan Manusia adalah salah satu indeks komposisi yang didasarkan pada tiga indikator, yakni (a) kesehatan, (b) pendidikan yang dicapai, (c) standar kehidupan.

Tiga unsur ini sangat penting dalam menentukan tingkat kemampuan suatu daerah untuk meningkatkan indeks Pembangunan Manusianya. Ketiga unsur tersebut tidak berdiri sendiri, melainkan saling mempengaruhi satu dengan yang lainya, selain itu juga dipengaruhi oleh faktor-faktor lain seperti ketersediaan kesempatan kerja, yang pada giliranya ditentukan oleh banyak faktor terutama pertumbuhan ekonomi, infrastruktur dan kebijakan pemerintah. Jadi, Indeks Pembangunan Manusia di suatu daerah akan meningkatkan apabila ketiga unsur tersebut dapat ditingkatkan. Kualitas sumber daya manusia ditentukan oleh berbagai faktor terutama pendidikan, kesehatan dan juga nilai-nilai budaya seperti etos kerja dan disiplin. Masalah pendidikan dan kesehatan menurut beberapa studi menunjukkan keterkaitan antara pembagunan manusia dan pertumbuhan ekonomi.
\end{abstract}

Kata Kunci: Pembangunan Manusia, IPM, Pertumbuhan Ekonomi

\section{PENDAHULUAN}

Tujuan utama dari pembangunan manusia, yaitu untuk memperbanyak pilihan-pilihan yang dimiliki manusia. Semakin tinggi pendidikan semakin banyak peluang-peluang yang bisa diraih. Pembangunan manusia melihat secara bersamaan semua isu dalam masyarakat, pertumbuhan ekonomi, perdagangan, ketenagakerjaan, kebebasan politik ataupun nilai-nilai kultural dari sudut pandang manusia. Demikian pula, pembangunan manusia tidak hanya memperhatikan sektor sosial, tetapi merupakan pendekatan yang komprehensif dari semua sektor.

Perkembangan pembangunan di Indonesia, selama ini sangat bertumpu pada pertumbuhan ekonomi. Pertumbuhan tersebut mengharuskan penduduk untuk mengalokasikan pengeluaran sendiri untuk kesehatan dan pendidikan lebih banyak. Sementara pengeluaran pemerintah untuk pelayanan seperti kesehatan dan pendidikan relatif sedikit. Kebutuhan akan peningkatan alokasi pengeluaran pemerintah untuk bidang sosial 
menjadi kian terasa sejak Indonesia mengalami krisis ekonomi. Krisis tersebut bukan hanya menyebabkan melorotnya pencapaian pembangunan tetapi juga membawa pengaruh buruk terhadap tingkat kemiskinan.

Faktor penyumbang laju pertumbuhan ekonomi ada empat, diantaranya investasi, pengeluaran pemerintah, konsumsi dan ekspor impor. Pemerintah selanjutnya, mengubah strategi pembangunan yang tidak hanya berorientasi pada pertumbuhan ekonomi tetapi juga kesejahteraan. Mulai saat ini perhatian pemerintah sudah saatnya mulai diberikan pada usahausaha untuk meningkatkan pembangunan masyarakat yang berorientasi pembangunan manusianya.

Sehubungan dengan itu maka investasi pada pendidikan dan kesehatan sangat penting artinya bagi peningkatan laju pertumbuhan ekonomi. Persoalan akan arti pentingnya investasi sektor pendidikan dan kesehatan untuk pembangunan manusia juga berlaku untuk pemerintah daerah, terlebih setelah otonomi daerah. Selama ini pengeluaran pembangunan pemerintah daerah masih terkonsentrasi pada bidang infrastruktur ekonomi dan belum memberikan perhatian yang memadai bagi bidang pembangunan manusia serta efisiensi investasi sektor tersebut pun masih rendah.

Investasi sektor publik untuk bidang pembangunan manusia sangat diperlukan dalam rangka meningkatkan kualitas sumber daya manusia dan menekan tingkat kemiskinan. dewasa ini juga makin kuat kebutuhan agar pemerintah, termasuk pemerintah daerah untuk makin menaruh perhatian pada investasi tersebut yang komponen utamanya adalah pengeluaran untuk bidang pendidikan dan kesehatan dalam pengeluaran pembangunan.

Manajemen anggaran pemerintah sering kali terjadi tarik menarik antara investasi untuk infrastruktur ekonomi (fisik) dan investasi untuk sektor pembangunan sosial (manusia). Di suatu sisi pengeluaran investasi untuk infrastruktur dibutuhkan untuk memfasilitasi pertumbuhan ekonomi, namun disisi lain diperlukan juga investasi untuk meningkatkan kualitas sumber daya manusia. Pembangunan manusia yang berhasil sebetulnya juga memberikan manfaat positif bagi perubahan ekonomi melalui tersedianya tenaga kerja yang berkualitas. Dengan kata lain sesungguhnya terdapat hubungan dua arah antara pertumbuhan ekonomi dan pembangunan manusia.

Tingkat kemajuan suatu daerah atau Negara diukur dari besarnya pendapatan perkapita masyarakat yang hanya dapat ditingkatkan dengan pemanfaatan segala potensi yang dimiliki secara potensial seperti sumber daya alam, manusia dan modal. Perkembangan ekonomi dalam bentuk kenaikan pendapatan perkapita yang terjadi dalam kurun yang cukup 
lama biasanya disertai dengan proses transformasi sosial ekonomi. Salah satu bagian yang terpenting bagi proses tersebut adalah perubahan komposisi Produk Domestik Regional Bruto (PDRB) menurut sektor lapangan usaha.

Pertumbuhan ekonomi suatu daerah dapat dilihat dengan menganalisis peningkatan pendapatan daerah yang dilihat dari hasil produksi barang dan jasa yang dihasilkan oleh daerah tersebut selama periode tertentu. Peningkatan penambahan dari periode ke periode inilah yang dijadikan sebagai analisis untuk melihat pertumbuhan ekonomi daerah.

Todaro (2004), mengatakan pembangunan itu harus dipandang sebagai suatu proses perubahan multidimensional yang mencakup perubahanperubahan penting dalam struktur sosial, sikap-sikap masyarakat dan lembaga-iembaga ekonomi dan akselerasi pertumbuhan ekonomi, pengurangan kesenjangan dan pemberantasan kemiskinan absolut. Selanjutnya pembangunan ekonomi periu dipandang sebagai kenaikan dalam pendapatan perkapita, karena kenaikan itu merupakan penerimaan dari timbulnya perbaikan kesejahteraan masyarakat.

\section{Metode Penelitian}

\section{Jenis Data dan Sumber Data}

Jenis data yang digunakan ada time series (runtut waktu). Time series (runtut waktu adalah data yang dikumpulkan dari waktu ke waktu pada satu obyek dengan tujuan untuk menggambarkan perkembangan, sedangkan sumber-sumber data dapat diperoleh dari instansi yang, terkait dengan penelitian ini.

\section{Metode Pengumpulan Data}

Dalam melakukan penelitian ini, metode pengumpulan data yang digunakan adalah penelitian kepustakaan, dimana akan memperoleh data sekunder. Data sekunder yang digunakan dimungkinkan berasal dari hasil penelitian yang belum diproses dan dianalisis lebih lanjut, sehingga dapat menghasilkan sesuatu yang berguna.

\section{Metode Analisis}

\section{A. Analisis Deskriftif Kualitatif}

Analisis Deskriftif disajikan dalam bentuk data dan tabel serta fenomena yang terdapat dalam data yang selanjutnya dilakukan analisis terhadap perubahan dan fenomena yang terdapat dalam data-data tersebut. Dan memaparkan variabel yang 
akan dibahas serta kemudian dilakukan perbandingan antara teori dengan kenyataan yang ada.

\section{B. Analisis Deskriftif Kuantitatif}

Alat analisis yang digunakan dalam penelitian ini adalah alat analisis kuantitatif dengan metode ekonometrika analisis Regresi Linier sederhana (Arief, Sritua: 1993). untuk mengetahui pengaruh Indeks Pembangunan Manusia (IPM) terhadap pertumbuhan ekonomi di Kota Jambi digunakan model analisis regresi sederhana dengan rumus :

Fungsi pertama dapat diubah dalam bentuk persamaan linear :

$$
\mathrm{Y}=\alpha+\beta_{1} \mathrm{x}_{1}+\beta_{2}+\ldots \ldots . \mathrm{e}
$$

Dimana

$$
\begin{array}{ll}
\mathrm{Y} & =\text { Produk Domestik Regional Bruto (PDRB) } \\
\mathrm{a} & =\text { Konstanta } \\
\beta_{1.2} & =\text { Koefisien Regresi } \\
\mathrm{X} 1 & =\text { Rata-rata Lama Sekolah } \\
\mathrm{e} & =\text { Standar error }
\end{array}
$$

Untuk melihat kinerja pertumbuhan ekonomi digunakan Produk Domestik Regional Bruto (PDRB). Adapun untuk indikator pembangunan manusia dalam hal ini digunakan Rata-rata Lama Sekolah (RLS). Rata-rata Lama Sekolah merupakan salah satu komponen dari Indeks Pembangunan Manusia. Komponen lainya adalah tingkat melek huruf dewasa, dan pengeluaran perkapita.

$$
P D R B=\frac{P_{n}-P_{n-1}}{P_{n-1}}
$$

Dimana :

$\mathrm{P}_{\mathrm{pdrb}} \quad$ : perkembangan PDRB .

Pn : Jumlah PDRB terhadap yang di hitung

$\mathrm{P}_{\mathrm{n}-1} \quad$ : Jumlah PDRB tahun sebelumnya 


\section{PEMBAHASAN}

Perkembangan Pembangunan Manusia di Kota Jambi

Perkembangan Rata-Rata Lama Sekolah

Ukuran tingkat pendidikan digunakan Rata-rata Lama Sekolah (RLS) penduduk. Ratarata Lama Sekolah adalah komponen dari Indeks Pembangunan Manusia (IPM) yang mengukur lama sekolah (tahun) penduduk usia 15 tahun ke atas. Berikut gambaran tingkat Rata-rata Lama Sekolah (RLS) di Kota Jambi pada tahun 2002-2011.

Tabel 1 . Rata-rata Lama Sekolah Penduduk di Kota Jambi Tahun 2002-2011.

\begin{tabular}{|c|c|}
\hline Tahun & $\begin{array}{c}\text { Rata-rata Lama Sekolah Tenaga Kerja } \\
\text { (Tahun) }\end{array}$ \\
\hline 2002 & 9.7 \\
\hline 2003 & 9.8 \\
\hline 2004 & 9.9 \\
\hline 2005 & 10.1 \\
\hline 2006 & 10.1 \\
\hline 2007 & 10.1 \\
\hline 2008 & 10.1 \\
\hline 2009 & 10.11 \\
\hline 2010 & 10.11 \\
\hline Rata-rata & 10.37 \\
\hline BPS Kota & $\mathbf{1 0 . 0 4}$ \\
\hline
\end{tabular}

Sumber : BPS Kota Jambi

Dari tabel di atas dapat terlihat bahwa Rata-rata Lama sekolah di Kota Jambi mengalami peningkatan. Dari data yang ada menunjukkan rata-rata lama sekolah penduduk usia 15 tahun ke atas di Kota Jambi rata-rata 10,04 per tahun atau telah bersekolah menengah pertama.

Tabel 2. Indeks Pembangunan Manusia (IPM) Tahun 2002-2011

\begin{tabular}{|c|c|}
\hline Tahun & $\begin{array}{c}\text { Indeks Pembangunan Manusia (IPM) } \\
\text { (Tahun) }\end{array}$ \\
\hline 2002 & 71.4 \\
\hline 2003 & 72.8 \\
\hline 2004 & 75.5 \\
\hline 2005 & 74.1 \\
\hline 2006 & 74.5 \\
\hline 2007 & 75.1 \\
\hline 2008 & 75.47 \\
\hline 2009 & 75.79 \\
\hline 2010 & 76.07 \\
\hline 2011 & 76.60 \\
\hline Rata-rata & $\mathbf{7 4 . 5 3}$ \\
\hline
\end{tabular}

Sumber : BPS Kota Jambi 
Dari tabel di atas terlihat bahwa Indeks Pembangunan Manusia (IPM) Kota Jambi mengalami peningkatan. Dari data yang ada menunjukkan Indeks Pembangunan Manusia di Kota Jambi dengan Rata rata 74,533 per tahun. Peningkatan ini tentunya memberikan gambaran keberhasilan Kota Jambi dalarn upaya Pembangunan Manusia aspek tersebut berkaitan dengan peluang hidup (longevity), pengetahuan (knowledge) dan hidup layak (decent living).

\section{Analisis Pengaruh Pembangunan Manusia Terhadap Pertumbuhan Ekonomi Kota Jambi}

Untuk melihat pengaruh pembanguan manusia terhadap pertumbuhan ekonomi Kota Jambi yang tercermin dari Rata-rata Lama Sekolah (RLS) terhadap perkembangan Produk Domestik Regional Bruto (PDRB) Kota Jambi, dapat dilihat dari tabel. 3 di bawah ini;

Tabel 3. : Analisis Pengaruh Pembangunan Manusia Terhadap Pertumbuhan Ekonomi di Kota Jambi

\begin{tabular}{|c|c|c|}
\hline Tahun & $\begin{array}{c}\text { Pertumbuhan Ekonomi } \\
\text { Kota Jambi }\end{array}$ & $\begin{array}{c}\text { Perkembangan Rata-rata } \\
\text { Lama Sekolah (RLS) }\end{array}$ \\
\hline 2002 & 2.15 & 9.7 \\
\hline 2003 & 2.26 & 9.8 \\
\hline 2004 & 2.37 & 9.9 \\
\hline 2005 & 2.61 & 10.1 \\
\hline 2006 & 2.66 & 10.1 \\
\hline 2007 & 2.85 & 10.1 \\
\hline 2008 & 3.02 & 10.1 \\
\hline 2009 & 3.22 & 10.11 \\
\hline 2010 & 3.43 & 10.11 \\
\hline 2011 & 3.67 & 10.37 \\
\hline
\end{tabular}

Sumber : BPS, Kota Jambi. (Data diolah).

Dari hasil persamaan regresi sederhana pengaruh variabel bebas perkembangan Rata-rata Lama Sekolah (RLS) (variabel independent) terhadap variabel terikat Pertumbuhan Ekonomi Kota Jambi (dependent), ini dapat dilihat dari perkembangan Rata-rata Lama sekolah di Kota Jambi mengalami peningkatan. Dari data yang ada menunjukkan rata rata lama sekolah penduduk usia 15 tahun ke atas di Kota Jambi rata-rata 10,04 per tahun atau telah bersekolah menengah pertama. Sedangkan untuk Indeks Pembangunan Manusia (IPM) Kota Jambi mengalami peningkatan. Dari data yang ada menunjukkan Indeks Pembangunan Manusia di Kota Jambi dengan Rata-rata 74,533 per tahun. Peningkatan ini tentunya memberikan 
gambaran keberhasilan Kota Jambi dalam upaya Pembangunan Manusia aspek tersebut berkaitan dengan peluang hidup (longevity), pengetahuan (knowledge) dan hidup layak (decent living) dari tahun 2002-2011

Untuk hasil estimasi fungsi tersebut dengan menggunakan program SPSS. Dan hasil ini dapat dilihat koefisien regresi dan t-hitung pada masing-masing variabel independent seperti tabel dibawah ini :

Tabel 4 : Nilai koefisien regresi dan t-hitung dari variabel independent dalam Analisis Pengaruh Pembangunan Manusia Terhadap Pertumbuhan Ekonomi di Kota Jambi periode 2002-2011

Coefficients $^{\mathrm{a}}$

\begin{tabular}{|l|r|r|r|r|r|}
\hline & \multicolumn{2}{|c|}{$\begin{array}{c}\text { Unstandardized } \\
\text { Coefficients }\end{array}$} & $\begin{array}{c}\text { Standaridized } \\
\text { Coefficient }\end{array}$ & $\mathrm{t}$ & $\mathrm{Sig}$ \\
\hline & \multicolumn{1}{|c|}{$\mathrm{B}$} & Std. Error & Beta & & \\
\hline RLS & 5.105 & .281 & & 18.140 & .000 \\
& .137 & .029 & .859 & 4.756 & .001 \\
\hline
\end{tabular}

Model Summary

\begin{tabular}{|c|c|c|c|c|c|c|c|c|c|}
\hline \multirow[b]{2}{*}{ Model } & \multirow[b]{2}{*}{$\mathrm{R}$} & \multirow[b]{2}{*}{$\begin{array}{c}\mathrm{R} \\
\text { Square }\end{array}$} & \multirow[b]{2}{*}{$\begin{array}{c}\text { Adjusted R } \\
\text { Square }\end{array}$} & \multirow{2}{*}{$\begin{array}{c}\text { Std. Error } \\
\text { of the } \\
\text { Estimate }\end{array}$} & \multicolumn{5}{|c|}{ Change Statistics } \\
\hline & & & & & $\begin{array}{c}\text { R Square } \\
\text { Change }\end{array}$ & $\begin{array}{c}\mathrm{F} \\
\text { Change }\end{array}$ & $\mathrm{df1}$ & $\mathrm{df} 2$ & Sig. F Change \\
\hline 1 & $.610^{a}$ & .789 & .293 & .48365 & .372 & 4.732 & 1 & 8 & .061 \\
\hline
\end{tabular}

a. Predictors: (Constant), RLS

$$
\begin{aligned}
\mathrm{Y} & =5,105+0,137 \mathrm{X}_{1}+\mathrm{e} \\
& =(0,281)(0,029) \text { Standar Eror } \\
& =(18,140)(4,756) \mathrm{t}_{\text {hitung }} \\
\mathrm{t}_{\text {tabel }} & =2,262 \\
\mathrm{R} & =0,610 \\
\mathrm{R}^{2} & =0,789
\end{aligned}
$$

Dari persamaan diatas dapat ditafsirkan bahwa setiap kenaikan Rata-rata lama sekolah sebesar 1 persen maka PDRB Provinsi Jambi akan mengalami peningktan sebesar 0,137 persen.

Dengan demikian secara ekonomi upaya pertumbuhan ekonomi pada setiap sektor ekonomi berdampak terhadap Indeks Pembangunan Manusia seperti halnya Sumber daya manusia yang sangat penting. 


\section{Kesimpulan dan Saran}

\section{Kesimpulan}

1. Dari hasil perhitungan diperoleh nilai koefisien determinasi ( $R$ 2) sebesar 0,789 yang mengandung arti bahwa variabel bebas yaitu rata-rata lama sekolah $(\mathrm{X}$,$) dapat$ menerangkan variabel pertumbuhan ekonomi (I) yakni yang menunjukan $78.9 \%$ perubahan pertumbuhan ekonomi diterangkan oleh variabel bebas yaitu rata-rata lama sekolah. Sementara $21.1 \%$ dipengaruhi oleh variabel lain yang tidak termasuk dalam penelitian ini.

2. Hasil uji hipotesis menunjukkan secara parsial (uji individu) rata-rata lama sekolah berpengaruh signifikan terhadap PDRB (pertumbuhan ekonomi) Kota Jambi.

\section{Saran}

1. Pendidikan sebagai satah satu indikator Indeks Pembangunan Manusia (IPM) sangat mempengaruhi pembangunan ekonomi. Pembangunan dibidang pendidikan akan membawa dampak positit, sehingga diperlukan upaya peningkatan kualitas sumber daya manusia dari sisi pendidikan.

2. Diharapkan pemerintah perlu lebih mengedepankan upaya peningkatkan kualitas sumber daya manusia melalui program-program pembangunan yang lebih berorientasi pada pemenuhan kebutuhan pendidikan baik forman maupun non formal.

\section{DAFTAR PUSTAKA}

Arsyad, Lincolin (2004); Ekonomi Pembangunan penerbit STIE - YKP Yogyakarta.

Arsyad, Lincolin (2005), Pengantar Perencanaan dan Pembangunan Ekonomi daerah, Edisi Pertama, BPFE, Yogyakarta

Djojohadikusumo, Sumitro (2005). .Perkembangan Pemikiran Ekonomi Dasar Teori Pertumbuhan dan Ekonomi Pembangunan, LP3ES, Jakarta

Djohanputro, Bramantyo, 2008, Prinsip prinsip Ekonomi Makro, Cetakan II, PPM Jakarta 
Kuncoro, Mudrajad, 2000, Ekonomi Pembangunan, UPP YKPN, Yogyakarta

Kuncoro, Mudrajad 2004, Otonomi dan Pembangunan Daerah, Erlangga, Jakarta.

Mulyadi, 2006, Ekonomi Sumber Daya Manusia dalam Perspektif, Pembangunan, Edisi Revisi, Penerbit PT. Rajagrafindo Persada, Jakarta

Nopirin, 2000, Ilmu Ekonomi, BP FE-UGM, Yogyakarta

Suryana, Hadiatdja, 2000, Ekonomi Sumber Daya Manusia, Penerbit Salemba Empat, Jakarta

Susanti, Ikhsan, dan Widyanti, 2005, Indikator Ekonomi Makro, LP FE-UI, Jakarta 